\title{
A blasfêmia: suas interfaces em contexto bilíngue
}

\author{
Vitalina Maria Frosi*
}

Resumo: Este artigo focaliza a prática da blasfêmia em uso no contexto de línguas em contato de português e italiano, na região de colonização italiana do nordeste do Rio Grande do Sul. Aborda aspectos gerais do turpilóquio em suas interfaces com a língua, com a cultura e com a identidade dos ítalo-descendentes. Os dados foram levantados através de pesquisa de campo realizada com entrevistas semiestruturadas, abrangendo, além da área de colonização italiana, também as áreas limítrofes de colonização alemã. A pesquisa tem caráter qualitativo. Este trabalho dá realce à blasfêmia e a seus eufemismos, buscando suporte teórico em estudos específicos desenvolvidos por pesquisadores italianos. A blasfêmia é analisada aqui como um elemento cultural típico do mundo italiano. Sua prática constitui um fenômeno de aparente contradição com a fé e com o espírito religioso da doutrina católica que sempre norteou a vida dos ítalo-brasileiros. Proferida em dialeto italiano, a blasfêmia estende seu domínio além do bilinguismo que está em vias de extinção. Os eufemismos, como atenuantes da ofensa dirigida a Deus e às outras divindades, passam também a exercer o papel de marcadores da fala, por vezes, esvaziados do sentido original.

Palavras-chave: blasfêmia; eufemismo; italiano; cultura.

Resumen: Este artículo enfoca la práctica de la blasfemia en el contexto de lenguas en contacto de portugués e italiano, en el área brasileña del nordeste del estado de Rio Grande do Sul. Aborda aspectos generales del hablar grosero en sus interfaces con la lengua, con la cultura y con la identidad de los ítalo- descendientes. Los datos fueron levantados a través de investigación de campo realizado con entrevistas semi-estructuradas, abarcando, además del área de colonización italiana, también las áreas limítrofes de colonización alemana. La investigación tiene carácter cualitativo. Este trabajo da realce a la blasfemia y a sus eufemismos, buscando soporte teórico en estudios específicos desarrollados por investigadores italianos. La blasfemia es analizada como un elemento cultural del mundo italiano. Su práctica constituye un fenómeno de aparente contradicción con el espíritu religioso de la doctrina católica que siempre dirigió la vida de los ítalo-descendientes. Proferida en dialecto italiano, la blasfemia extiende su dominio más allá del bilingüismo que está en vías de extinción. Los eufemismos, con atenuantes de la ofensa dirigida a Dios y a las otras divinidades, pasan también a ejercer el papel de marcadores del habla, vaciados del sentido original.

Palabras clave: blasfemia, eufemismo, italiano, cultura

Já disse: sou lúcido. Nada de estéticas com o coração: sou lúcido.

Merda! Sou lúcido. (Álvaro de Campos, Heterónimo de Fernando Pessoa).

\footnotetext{
* Doutora em Educação, docente do Departamento de Letras da Universidade de Caxias do Sul (UCS).
} 


\section{Introdução}

Este estudo insere-se na lexicologia, precisamente no segmento da linguagem que reúne o léxico do falar torpe, da blasfêmia, da ofensa, do ultraje, resumidamente, do turpilóquio. Levamos em conta o contexto bilíngue de português e dialeto italiano da Região de Colonização Italiana do nordeste do Rio Grande do Sul - RCI - definido, hoje, como instável, passivo e restrito, com solução evidente para o monolinguismo de língua portuguesa (FROSI; MIORANZA, 2009, p. 114-115; FAGGION, 2007, p. 136).

Partimos do pressuposto de que o turpilóquio está presente em todas as línguas conhecidas do mundo. Pelo seu uso e pelas suas especificidades, ele se constitui num fato social que, presumimos, tenha dimensões diversas e variadas, conforme os valores e a visão de mundo de cada povo.

As imprecações, os palavrões, os nomes injuriosos, o falar torpe em geral, a blasfêmia e seus vários eufemismos constituem um segmento da linguagem oral da RCI, ao que nos é dado saber, ainda não contemplado com estudos acadêmicos de caráter científico, além dos que têm sido realizados pela equipe do Projeto Turpilóquio, desenvolvido de 2007 a 2009, junto ao programa de Mestrado em Letras, Cultura e Regionalidade da Universidade de Caxias do Sul.

A investigação compreende também um breve estudo dos eufemismos. Buscamos entender qual seria a motivação para o uso da blasfêmia, que vem se estendendo no tempo da RCI por mais de 130 anos de sua história. Questionamos que sentido teria a permanência da prática da blasfêmia no seio do grupo étnico minoritário ítalo-brasileiro da RCI, mesmo no contexto atual em que o bilinguismo sofre anulação em favor do português.

Tivemos como objetivo principal analisar o turpilóquio em linhas amplas, aprofundando o estudo da blasfêmia, com foco nos aspectos culturais e nas formas linguísticas que lhe dão suporte. A blasfềmia foi estudada como elemento marcante do universo linguístico-cultural ítalo-gaúcho.

Outros objetivos, não menos importantes, estiveram presentes no desenvolvimento do trabalho, como o de dar, na medida do possível, uma explicação para o uso da blasfêmia em confronto com a religiosidade católica que sempre marcou a 
vida das pessoas das comunidades da amostra. Analisamos, brevemente, também as blasfêmias, tendo em conta o gênero e a faixa etária dos blasfemadores.

Nossa análise buscou suporte teórico em vários estudiosos que trabalharam sobre este tema ou em áreas afins. Dentre muitos, valemo-nos dos textos de Paratesi (1964; 2009); Tartamella (2006); Zanni (2000); Capuano (2007); Duranti (2002); Benveniste (2006); Aquino (1980); Greco (1994); Pinker (2008). Além desses, servimonos de outros, todos eles constantes nas referências bibliográficas, a seguir.

A investigação foi desenvolvida mediante levantamento e registro dos dados com pesquisa de campo. Usamos a entrevista semiestruturada. Além das entrevistas gravadas, incluímos os dados registrados por oitiva pelos componentes da equipe do projeto de pesquisa Turpilóquio. Para registro dos dados em situações espontâneas, assistiu-se a festas, partidas de futebol e a jogos de cartas nas bodegas ${ }^{1}$. Esta modalidade de ação mostrou-se necessária para compensar o silêncio e a inibição dos sujeitos, constrangidos em ter de proferir blasfêmias e outros nomes, quando solicitados a dar exemplos.

Valemo-nos, para o início da atividade, do material gravado em 2002 e 2003 por Marlei Zanetti, na época, aluna do curso de língua italiana da UCS. O material registrado nessa fase preliminar foi obtido através de entrevistas livres, feitas com informantes das localidades de Ana Rech - uma das regiões administrativas do município de Caxias do Sul - e de Vila Seca, um dos distritos desse mesmo município. Incluímos, outrossim, dados registrados em investigações anteriores. ${ }^{2}$ Partimos, assim, em 2007, para a pesquisa do falar torpe, com um conjunto de dados bastante

\footnotetext{
${ }^{1}$ A bodega é um estabelecimento frequentado pelos moradores das pequenas localidades rurais, em geral, no domingo, para jogarem cartas, tomar cerveja ou outra bebida e assistir a jogos de futebol. No passado, somente os homens frequentavam as bodegas; as mulheres se faziam presentes só no dia em que era festejado o santo padroeiro da capela da localidade. Hoje, a bodega é também chamada de salão e, às vezes, nela reúnem-se também as jovens da localidade, para conversar e ouvir música. Nas bodegas, realizam-se, normalmente, também os encontros das senhoras que compõem o Clube de Mães.

${ }^{2}$ Em 2004 e 2005, foi desenvolvido um projeto de pesquisa, intitulado "Linguagem da Região Colonial Italiana: prestígio e estigmatização", referido, comumente, pela sigla ESTIGMA. Esse projeto teve como objetivo geral realizar um estudo do binômio prestígio e estigmatização sociolinguística na comunidade de fala de Caxias do Sul e desenvolver uma explicação do fenômeno para melhor compreensão da relação entre linguagem e cultura da RCI (cf. FROSI; FAGGION; DAL CORNO, 2010). O instrumento utilizado na pesquisa do projeto ESTIGMA continha, além das questões atinentes aos objetivos daquele projeto, um módulo específico sobre a blasfêmia. Foram levadas em conta, também, as formas blasfêmias, espontaneamente produzidas pelos sujeitos das entrevistas sociolinguísticas do BDSer - Banco de Dados de Fala da Serra Gaúcha. Essa atividade foi desenvolvida no período de agosto de 2002 a julho de 2005 (cf. BATTISTI, Elisa et alii, 2006).
} 
significativo que serviu para aperfeiçoarmos o instrumento utilizado. Privilegiamos, como área para a realização da pesquisa de campo, os municípios de Caxias do Sul, Bento Gonçalves e Farroupilha. A delimitação desse espaço geográfico foi feita tendo em conta a representatividade numérica dos habitantes ítalo-gaúchos de origem vêneta, lombarda e trentina (cf. FROSI; MIORANZA, 1975). Ao mesmo tempo em que a amostra revelou ser representativa, mostrou-se, também, adequada por compreender as variedades linguísticas comuns a toda a RCI.

$\mathrm{Na}$ transcrição dos termos dialetais italianos (blasfêmias e eufemismos) adotamos o sistema ortográfico consignado no manual Grafia Veneta Unitaria (cf. CORTELAZZO et alii, 1995).

Em síntese, o trabalho foi realizado mediante pesquisa de campo, com utilização da entrevista semiestruturada e com acréscimo do material obtido por oitiva. A área selecionada compreendeu os três municípios mais populosos e economicamente mais desenvolvidos da RCI. A pesquisa teve caráter qualitativo.

\section{Palavras: seus usos, suas interfaces}

Através da linguagem articulada, o homem se situa no mundo como um ser diferente dos animais, superior a eles por sua expressão vocal. Por meio da língua, um grupo humano se identifica ou se distingue dos demais. Nesse sentido, dentre todas as espécies, o ser humano é o único dotado da capacidade de linguagem articulada, que é distinta das demais capacidades cognitivas. A língua, mais do que qualquer outro elemento cultural, sobretudo a língua materna, confere ao indivíduo uma identidade própria e o insere num grupo específico. "É indiscutível a importância que tem a língua materna na manifestação da cultura e da etnicidade de um grupo étnico" (FROSI, 2007, p. 148).

“A palavra étnica, como o elo de uma corrente, une uma geração à outra e, ao mesmo tempo, as separa na linha sucessória do tempo, no espaço habitado pelos homens" (FROSI, 2008, p. 128). Não só: “a palavra oral transpõe as distâncias, modifica-se de um lugar a outro por contatos diversos e variados. Acima de tudo, a língua de origem preserva e retém sinais inequívocos da cultura própria do grupo" (FROSI, 2008, p. 128), do seu mundo de valores e crenças, de suas fragilidades, de seus 
hábitos linguísticos e culturais recorrentes, levados adiante mesmo em território estrangeiro. Os dialetos italianos, transplantados na RCI pelos imigrantes do norte da Itália, constituíam o universo linguístico deles, em terras brasileiras do sul do Brasil, neste caso, em solo gaúcho (cf. FROSI; MIORANZA, 2009). Essencialmente orais, essas falas intermediaram o bem e o mal, a dor e a saudade, a insuficiência humana, o medo e a coragem, a fome e o alimento. Elas serviram o canto, as estórias e cantilenas, os ditos e provérbios, as preces e fórmulas benfazejas, o dizer bonito e o falar feio, os insultos e as blasfêmias. Os dialetos italianos foram trilhas por onde andaram os sentidos da vida, do tempo transcorrido, das travessias efetuadas, às vezes, com perdas, outras, com ganhos. As palavras são como esteiras: por elas passam e chegam ideias e sentimentos, reflexões e emoções; são signos diferenciadores entre os homens e todos os outros entes do mundo. As palavras carregam significados que se preservam de um país a outro e podem também adquirir novos sentidos ou se alterar. Assim, quando os emigrantes do norte da Itália fundaram povoados e cidades em terras brasileiras do nordeste do Rio Grande do Sul, aí instauraram seu modo de vida, suas crenças, seus costumes, suas tradições, sua linguagem, em síntese, uma tradição tipicamente vênetolombarda (cf. FROSI, 1989). Por meio dos diferentes sistemas dialetais, adquiridos no Norte da Itália, os ítalo-descendentes da RCI comunicaram-se no dia-a-dia do mundo circunstante, em família e na sociedade de seu tempo.

\section{Língua, cultura e identidade}

Com o termo identidade entende-se o próprio ser em contínuo processo, construindo-se através do tempo, reconstruindo-se no contexto em que se encontra e reconhecendo-se distinto de todos os outros. Nesse processo de construção e reconstrução da identidade, a língua sempre desempenhou um papel fundamental. (FROSI, 2008, p. 131).

Ao abordar a relação entre língua e cultura, tomando como suporte teórico princípios estabelecidos por Duranti (2002) e Kramsch (1998), Faggion (2010, p. 103) destaca que há uma característica permanente, válida e sustentada de forma comum nessas teorias: "o que todas têm em comum é a relação com a linguagem, inerente, básica”. Mais adiante, retomando a teoria de Kramsch (FAGGION, 2010, p. 
104), acrescenta que "os falantes estabelecem identidades (suas e dos outros) por meio dos usos da linguagem." Reportando-se à construção da identidade de um indivíduo, Dal Corno (2010, p. 77) diz que "é um processo contínuo ao longo da vida, mas, ao mesmo tempo, é profundamente marcada pelas respostas dadas pelo grupo que o circunda ainda em sua tenra idade".

Língua, cultura e identidade aproximam os ítalo-descendentes. Eles se reconhecem como iguais ou muito semelhantes, pertencentes a um mesmo grupo minoritário, falantes de uma variedade linguística por eles compartilhada, em oposição ao grupo majoritário do qual se diferenciam e dele se distinguem em muitos aspectos. $\mathrm{O}$ turpilóquio, nas suas várias expressões, especificamente, a blasfềmia identifica os ítalodescendentes, também por esse segmento linguístico e cultural. A blasfêmia e o falar torpe dialetal italiano não se desvincularam da história de vida dos ítalo-gaúchos da RCI.

Em seu livro Italiano, perché bestemmi? Cristiano, perché taci?, Dogo (1986, p. 15-16, tradução nossa) ${ }^{3}$ relata um caso interessante, extraído de uma carta, publicada em Vita del Popolo, jornal de Treviso, na data de 2 de maio de 1976:

"UMA BLASFÊMIA? ESTOU NA ITÁLIA...". "Devo dizer que as blasfêmias, as piores blasfêmias se ouvem, quase exclusivamente, em italiano. Alguns estrangeiros blasfemam em italiano porque aprenderam dos soldados ou dos operários italianos. Em 1959, voltando de Moçambique, via Portugal, dei-me conta de ter passado a fronteira de Ventimiglia, exatamente por ter ouvido blasfemar em italiano. Eram 4 horas da madrugada, ainda estava escuro e, dormitando, não tinha notado de ter atravessado a fronteira. Aquela blasfêmia funcionou como uma advertência. Notem que fazia 10 anos que eu estava ausente da Itália e que, em todo esse tempo, não tinha ouvido uma verdadeira blasfêmia"4.

\footnotetext{
${ }^{3}$ Assim, como fizemos essa tradução do texto original, as demais citações extraídas de obras escritas em italiano, constantes no decorrer deste trabalho, são traduções feitas pela autora deste texto.

4 “UNA BESTEMMIA? SONO IN ITALIA...". "Devo dire che le bestemmie, le peggiori bestemmie, si sentono quasi solo in italiano. Qualche straniero bestemmia in italiano perché ha imparato dai soldati o dagli operai italiani. Nel 1959, ritornando dal Mozambico, via Portogallo, mi accorsi di avere passata la frontiera di Ventimiglia, proprio per aver sentito bestemmiare in italiano. Erano le 4 del mattino, era ancora buio, e nel dormiveglia non avevo notato di aver superato la frontiera. Quella bestemmia mi servi da svegliarino. Notate che erano 10 anni dacché mancavo dall'Italia e che in tutto quel tempo non avevo sentito una vera bestemmia" (DOGO, 1986, p. 15).
} 
A língua, a cultura e a identidade do indivíduo são fortes aliadas, inseparáveis na trajetória de sua vida. Pela língua, o homem se insere num grupo social e, por ela, identifica-se com os demais membros desse grupo. É a língua que lhe possibilita o reconhecimento de igualdades e diferenciações com as pessoas do mundo em que vive. O falar torpe dialetal italiano constitui e ainda se confirma como um segmento importante do patrimônio linguístico e cultural dos ítalo-gaúchos. O palavrão e a blasfêmia fazem parte do viver e do modo de ser dos indivíduos ítalo-descendentes da RCI, do passado e do presente dessa região. A "palavrada", usando o termo registrado por Houaiss na definição de "turpilóquio", revela aos ouvintes informações várias de seus emitentes. Proferir palavrões ou blasfêmias pode, também, refletir um modo de expressar solidariedade entre pessoas que se identificam numa origem étnica e geográfica comum da RCI, na intimidade da família e em confronto com brasileiros de outras regiões do Brasil.

Das leituras efetuadas, colhemos informações de que os insultos, de modo geral, "como outras formas do discurso, são um produto da sociedade na qual são veiculados" (GARRIOCH, 1997, p. 121). Podemos pensar, assim, que toda sociedade tem formas próprias para expressar agressões, humilhar, ofender, ultrajar, provocar riso. Além disso, postulamos que determinados itens lexicais e sequências linguísticas, usados na expressão do falar torpe, são específicos de cada língua; contudo, como as demais funções da linguagem, a emotiva está presente em todas as línguas e culturas do mundo. Existem, portanto, duas características fundamentais para a esfera léxico-semântica do turpilóquio: a especificidade pertinente a cada língua e respectiva cultura e a universalidade que aproxima todas elas.

Pinker (2008, p. 378) considera que o

sabor emocional das palavras parece ser definido durante a infância: é comum que pessoas bilíngues não achem seu segundo idioma tão picante quanto o primeiro, e sua pele reage mais a tabuísmos e broncas ditos em sua primeira língua, se comparado aos equivalentes na segunda. 
Zanni (2001, p. 5) diz que “o insulto é expressão profunda do espírito e [...] enquanto denuncia defeitos e imperfeições de um indivíduo, abre rupturas inesperadas na natureza de quem o pronuncia."5

Os palavrões são vistos comumente como indícios de incivilidade, como prova de grosseria e de falta de boa educação, sobretudo, como uma marca de pessoa que não é refinada. O léxico representativo de blasfêmias e de palavrões ocupa um setor da língua, às vezes, evitado pelos próprios estudiosos. Capuano (2007, p. 11), entretanto, diz que os palavrões constituem um assunto para reflexão, repleto de revelações que regulam o comportamento social e fazem de homens e mulheres isto que são. $O$ turpilóquio revela estereótipos e preconceitos, mas também novos modos de ver a realidade, mais diretos e crus (CAPUANO, 2007, p. 12). Inúmeras são as nuanças de significado transmitidas na produção de nomes e expressões torpes. O falar torpe inclui desde a ofensa radical a Deus e a outras divindades até o uso corriqueiro de palavras de sentido vulgar, incivil e banal. Além disso, a linguagem como um todo revela a visão de mundo de seus utentes.

\section{A função linguística emotiva: a blasfêmia e os palavrões}

Dentre as várias funções linguísticas desempenhadas pelos sistemas da fala dialetal italiana, está a função emotiva ou expressiva que se alia, muitas vezes, à função conativa. A função expressiva não tem merecido estudos suficientes, no que diz respeito, principalmente, ao território da blasfêmia. A emotividade integra uma parcela significativa da vida do ser humano. Quando manifestada através da linguagem, pode assumir formas várias que se mostram e se definem, diversamente, na poesia, no amor, no linguajar corriqueiro de todas as horas, nas variedades linguísticas, no estilo de cada indivíduo. A emotividade perpassa e ilumina a palavra benéfica, mas pode também emergir do falar torpe, obscuro, vulgar e degradante, do maldizer, do blasfemar.

Ao apresentar o texto sobre as funções da linguagem, Mário Eduardo Martelotta (2008, p. 31) reporta-se ao estudo de Karl Bühler, ao de M. A. K. Halliday e, particularmente, àquele desenvolvido por Roman Jakobson (1969). Numa mensagem,

\footnotetext{
${ }^{5}$ L'insulto è espressione profonda dell'animo e [...] mentre denuncia difetti e manchevolezze di un individuo, apre squarci improvvisi sulla natura di chi lo pronuncia (ZANNI, 2001, p. 5).
} 
estão presentes aspectos que podem ser interpretados de acordo com a função predominante expressa por ela; contudo, outros aspectos dessa mesma mensagem podem desempenhar uma segunda função, vale dizer, que uma única mensagem pode ser multifuncional. De acordo com Jakobson (1969, p. 19), “Às vezes, essas diferentes funções agem em separado, mas normalmente aparece um feixe de funções." Das seis funções estudadas por Jakobson (1969, p. 122-131) - a referencial, a poética, a fática, a metalinguística, a emotiva e a conativa -, escolhemos as duas últimas por apresentarem um interesse maior no estudo do turpilóquio e, especificamente, no da blasfêmia.

A função emotiva centraliza-se no remetente, que fica envolvido numa explosão de sentimentos. A função conativa também é importante, pois se centraliza no destinatário a quem é dirigida a ofensa. Duranti (2002, p. 255) aponta, como exemplo clássico da função emotiva, o uso "das interjeições [...] e algumas modificações de sons linguísticos" $"$ que transmitem informações do estado de ânimo do emissor. Para a função conativa dá, como exemplo clássico, a atualização do vocativo, uma vez que a mensagem é dirigida a um destinatário.

A diferença entre a função referencial, de um lato, e do outro as funções conativa e emotiva é que só quando utilizamos a primeira torna-se possível estabelecer o valor de verdade do que estamos dizendo: nos outros dois casos, com efeito, não é correto formular um juízo com valor de verdade funcional ${ }^{7}$ (DURANTI, 2002, p. 255).

A blasfêmia mostra-se um caso peculiar de palavras ou de locuções que agregam, principalmente, as funções emotiva e conativa, com predominância da primeira. $\mathrm{O}$ falar torpe tem como função principal exprimir sentimentos negativos. Ele pode manifestar furor, ódio, grosseria, debilidade, rancor, aversão pelo outro, frustração. As funções emotiva e conativa muito têm sido analisadas e estudadas, particularmente, nos textos literários, no papel desempenhado na produção de efeitos estilísticos. Pouco se tem feito, nesse sentido, na linguagem popular da RCI, no âmbito da blasfêmia e do turpilóquio, em geral.

\footnotetext{
${ }^{6}$ Delle interiezioni [...] ed alcune modificazioni di suoni linguistici (DURANTI, 2002, p. 255).

${ }^{7}$ La differenza tra la funzione referenziale, da un lato, e dall'altro le funzioni conativa ed emotiva è che solo quando utilizziamo la prima diviene possibile stabelire il valore di verità di ciò che stiamo dicendo negli altri due casi, infatti, non è corretto formulare un giudizio di carattere verofunzionale (DURANTI, 2002, p. 255).
} 


\section{A blasfêmia e o turpilóquio na Itália}

E oh Merda! São as últimas palavras registradas mais frequentemente nas caixas pretas de um desastre aéreo. ${ }^{8}$ (TARTAMELLA, 2006, p. $10)$.

A palavra blasfêmia tem origem grega "blasphèmía, 'palavra de mau augouro' 'palavra ímpia' 'calúnia, difamação;" no latim, a forma é blasphēmia (CUNHA, 1982, p. 113). "Blasfêmia é um enunciado ou palavra que insulta a divindade, a religião ou o que é considerado sagrado" (HOUAISS, 2001, p. 466). Turpilóquio tem, no latim, a forma turpiloquium, compõe-se de turpis "torpe" e loqui "falar". É o modo de se exprimir obsceno ou blasfemo, ofensivo, referentemente à moral individual ou à pública decência (DEVOTO; OLI, 1990, p. 2046). O falar torpe é definido como desonesto, ofensivo e repugnante em relação à honestidade e ao pudor, frequentemente, com um sentido marcante de vulgaridade (CORTELAZZO; ZOLLI, 1988, p. 1386). O Dicionário Houaiss da língua portuguesa (HOUAISS, 2001, p. 2789) registra para turpilóquio essa mesma etimologia latina, isto é, turpis "torpe" e -loquium "falar" e define-o como "conversação torpe ou obscena; palavrada".

As blasfêmias e outros termos compreendidos no falar torpe são realmente antigos e presumimos que estejam presentes em todas as línguas conhecidas. "Não por acaso, os palavrões estão entre as palavras mais antigas - talvez as primeiras - na história do homem. Os palavrões, com efeito, marcaram o início da civilidade: em vez de se atirarem pedras, os homens aprenderam a se lançar... palavras. Achais pouco?"9 (TARTAMELLA, 2006, p. 9).

Em seu estudo, Capuano (2007, p. 11) diz que "turpilóquio e blasfềmias constituem [...] um fascinante assunto para reflexão, repleto de profundas revelações sobre os mecanismos que regulam o comportamento social e fazem de homens e

\footnotetext{
${ }^{8}$ E "Oh merda sono le ultime parole registrate più spesso sulle scatole nere prima di un disastro aereo." (TARTAMELLA, 2006, p. 10).

${ }^{9}$ Non a caso, le parolacce sono fra le parole più antiche - forse le prime - nella storia dell'uomo. Le parolacce, infatti, hanno segnato l'inizio della civiltà: invece di scagliarsi pietre, gli uomini hanno imparato a lanciarsi... parole. Vi pare poco? (TARTAMELLA, 2006, p. 9).
} 
mulheres isto que são."10 Mais adiante, discorrendo sobre a complexidade do turpilóquio e da blasfêmia, Capuano (2007, p. 20) traz à baila o caráter de universalidade.

O turpilóquio e a blasfêmia representam comportamentos sociais dentre os mais difundidos e transversais. Empregando uma terminologia habitual nas ciências sociais, pode-se dizer que eles são fatos sociais universais no sentido de que pertencem a todas as sociedades até aqui conhecidas. Em cada comunidade, determinadas palavras foram consideradas nocivas à ordem social e, como tais, censuradas e confirmadas. Não existe uma sociedade na qual as palavras tenham podido fluir livremente sem alguma forma de controle. $^{11}$

A prática da blasfêmia, registrada em muitos textos documentais, é confirmada já no Velho Testamento (SCANELLO, 2004, p. 28). Em seu livro Elogio della Bestemmia, Scanello (2004), dá informações preciosas sobre a prática antiga da blasfêmia na Itália, sobre a função por ela desempenhada no passado e sobre os motivos que levavam as pessoas a blasfemarem. Ele afirma que a blasfêmia acompanhou o homem através dos séculos.

De acordo com Giovanni Greco (1994, p. 13), a blasfêmia foi praticada até nos períodos de maior intensidade espiritual. Greco (1994, p. 42) informa que, em Veneza, a blasfêmia era largamente praticada. Os blasfemadores que não tinham condições de pagar a multa estabelecida, já no século XIII, eram publicamente expostos ao ridículo e, alguns anos após, cortavam-lhes a língua.

$\mathrm{Na}$ Itália do passado, quando uma blasfêmia era proferida publicamente, recebia tratamento punitivo na forma da lei. Além disso, uma multa era aplicada a todo cidadão que incorresse nesse ato. A produção de blasfêmias é referida, ainda, pela existência de

10 Turpiloquio e bestemmie rappresentano [...] un affascinante argomento di riflessione, gravido di profonde rivelazioni sui meccanismi che regolano il comportamento sociale e fanno di uomini e donne ciò che sono. (CAPUANO, 2007, p. 11).

${ }^{11}$ Il turpiloquio e la bestemmia rappresentano comportamenti social tra $i$ più diffusi e trasversali. Adoperando una terminologia consueta nelle scienze sociali, si può dire che essi sono fatti sociali universali nel senso che appartengono a ogni società fin qui conosciuta. In ogni comunità, determinate parole sono state ritenute lesive dell'ordine sociale e, come tali, censurate e sanzionate. Non esiste una società in cui le parole abbiano potuto fluire liberamente senza una qualche forma di controllo (CAPUANO, 2007, p. 20). 
numerosos processos dos séculos XVI e XVII contra os blasfemadores. Reportando-se às penas infligidas aos blasfemadores, Scanello informa que:

[...] tratava-se, de fato, de uma atividade criminalizada, por isso, perigosa e tornada clandestina pelo terror das penas espantosas previstas para os blasfemadores. Para a blasfêmia, que é a máxima violência possível contra Deus, tinha sido prevista, desde a origem a pena capital, a morte infamante ${ }^{12}(2004$, p. 28).

Em Veneza, uma das punições impostas aos blasfemadores era o suplício da cheba. A cheba era uma espécie de caixa quadrada, de madeira, fortificada com ferro, feita à semelhança de gaiola. Essa caixa era suspensa a uma viga que saía para fora do Campanário de São Marcos, acima das casas de pão. Dentro dela era posto o condenado por haver cometido delito grave, ficando aí por tempo indeterminado, às vezes, até a morte. Este tipo de suplício era, particularmente, aplicado aos condenados que eram clérigos, quando praticavam delitos enormes e assaz escandalosos. A cheba acabou em 1518 (BOERIO, 1993, p. 162).

Analisando a questão da blasfêmia e referindo-se ao texto do Artigo 724 do Código Penal da Constituição da Itália e à punição prevista em lei, Greco (1994, p. 85) diz que a penalidade aplicada à blasfêmia era "a multa que vai de oitocentas a vinte e quatro mil liras, seguindo o mesmo critério adotado para outro delito que, frequentemente, $a b$ antiquo (grifo do autor), foi considerado próximo à blasfêmia, isto é, o ultraje aos defuntos". ${ }^{13}$

No passado, blasfemava-se muito, até por motivos jocosos, num clima de grande intimidade e familiaridade que bem caracterizava as comunidades camponesas, diz Scanello (2004, p. 32). Todavia, observa o mesmo estudioso: "Hoje a blasfêmia tornouse um odioso e banal marcador de fala de colarinhos brancos [...], um rito profissional e não mais uma invocação". ${ }^{14}$

${ }^{12}$ [...] si trattava di fatto di un'attività criminalizzata, quindi pericolosa e resa clandestina dal terrore per le pene spaventose previste per $i$ bestemmiatori. Per la bestemmia, che è la massima violenza possibile contro Dio, era stata prevista sin dall'origine la pena massima, la morte infamante.

${ }^{13}$ L'ammenda [...] va dalle ottocento alle ventiquattromila lire alla stregua di un altro reato che spesso, 'ab antiquo', è stato ritenuto vicino alla bestemmia, e cioè, l'oltraggio ai defunti (GRECO, 1994, p. 85).

${ }^{14}$ Oggi la bestemmia è diventata un odioso e banale intercalare da colletti bianchi [...] $\grave{E}$ un rito professionale e non più un'invocazione (SCANELLO, 2004, p. 32) 


\title{
A blasfêmia e o eufemismo
}

Na Suma Teológica, no Artigo I, Tomás de Aquino diz que há três espécies de blasfêmias: "uma atribui a Deus o que não lhe convém; outra, dele remove o que the convém; a terceira atribui à criatura o que só é próprio de Deus. Por onde, a blasfềmia não é relativa só a Deus, mas também às criaturas." (AQUINO; apud COSTA; DE BONI, 1980). No Artigo II dessa mesma obra, a discussão gira em torno da questão que busca saber se a blasfêmia é ou não pecado mortal, como também analisa o pecado de blasfêmia, reconhecendo-o como o maior de todos.

\begin{abstract}
A blasfêmia é uma injúria dirigida contra Deus. Pode ter o caráter de injúria direta; então, sua mais grave forma é o insulto, o ultraje ciente e deliberado atirado contra Deus, com a intenção de ofendê-lo em sua honra e em sua santidade (blasfêmia diabólica). A blasfêmia assume frequentemente a forma de censura feita a Deus, por causa de alguma desgraça acontecida (HÄRIN, 1960, p. 261).
\end{abstract}

Em seu livro Parolacce; perché le diciamo, che cosa significano, quali effetti hanno, Tartamella (2006, p. 16) diz que a blasfêmia consiste numa agressão voluntária à divindade, aos símbolos ou aos santos de uma fé. A blasfêmia é uma afronta porque, proferindo-a, se rebaixa ao nível terreno o Ser mais alto. A blasfêmia pode consistir numa ofensa feita a Deus de forma indireta, isto é, pode ser dirigida à Mãe de Deus ou aos santos. Assim entendida, a blasfềmia apresenta traços fundamentais que estão em correspondência semântica com aqueles constantes nos conceitos expressos por muitos estudiosos do assunto e também com aqueles consignados em bons dicionários, dentre eles, o de Zingarelli (1983) e o de Devoto e Oli (1990); Houaiss (2001). De um modo geral, entende-se que a blasfêmia consiste numa expressão injuriosa, radical, dirigida contra Deus, contra Nossa Senhora, contra outra divindade ou contra objetos e símbolos sagrados. Pela blasfêmia, o blasfemador exterioriza sua própria intimidade com Deus, não através de um colóquio místico, mas rebaixando sua divindade à condição terrestre, material e vulgar. Esse tipo de aproximação ultrajante do espiritual com o material incorpora o que, no âmbito da Igreja Católica, é comumente chamado de pecado mortal, só absolvido ao blasfemador através da confissão verbalizada feita a um ministro de Deus e, mediante a bênção desse, acrescida do cumprimento da penitência que lhe for imposta. 
A blasfêmia é atualizada em diferentes formas, das quais umas são consideradas básicas e outras constituem múltiplas variantes vocabulares, algumas das quais são classificadas como eufemismos. Ela compreende um repertório lexical importante, revelador da faculdade criativa do homem, manifestada, sobretudo, por elementos linguísticos continuamente alterados, renovados e recriados (cf. FROSI; FAGGION; DAL CORNO, 2010). A blasfêmia é um dos componentes do léxico da língua e, como tal, suas múltiplas formas relacionam-se com a visão de mundo do grupo humano que a pratica.

Não estabelecemos aqui a distinção entre blasfêmia e imprecação; para fazê-lo com rigor científico, teríamos de reconstruir com total fidelidade também a exata entoação, em todos os casos de uma e de outra formulação blasfema. Sobre essa questão remetemos à análise minuciosa do estudo de Benveniste (2006) como também sugerimos a explicação detalhada constante na obra de Tartamella (2006), que apresenta múltiplas e elucidativas exemplificações.

O eufemismo é uma figura retórica usada para atenuar o sentido fortemente brutal e ferino de algumas palavras ou expressões chocantes aos ouvintes. O eufemismo pode ser representado por uma palavra, por uma locução ou ainda por uma perífrase. $\mathrm{O}$ uso dessa figura retórica visa a amenizar e a diminuir o impacto que a atualização de uma blasfêmia poderia causar nos ouvintes sem a utilização desse recurso.

Analisando este binômio - blasfềmia e eufemismo -, Benveniste (2006, p. 262 afirma que: "A eufemia não refreia a blasfêmia, ela a corrige na sua expressão de fala e a desarma enquanto imprecação". Nesse mesmo texto, detalhando a questão da blasfêmia e da eufemia, ele esclarece que:

[...] o repertório das locuções blasfêmicas tem sua origem e encontra sua unidade numa característica singular: ele procede da necessidade de violar a interdição bíblica de pronunciar o nome de Deus. A blasfêmia é de ponta a ponta um processo de fala; ela consiste, de uma certa maneira, em substituir o nome de Deus por sua injúria (BENVENISTE, 2006, p. 259-260).

A interdição, a necessidade de violar essa interdição e o uso do eufemismo estão intimamente conexas à blasfêmia. $\mathrm{O}$ processo blasfemo pode ser freado pela interdição do ato de conspurcar e ofender o nome de Deus, de Nossa Senhora, de outras divindades 
e dos símbolos sagrados, mas, ao mesmo tempo em que isso se dá, é liberado pelo uso do eufemismo que substitui a blasfêmia. Benveniste (2006, p. 260) alerta para a natureza da interdição como podemos entender pelo trecho que segue:

É preciso prestar atenção à natureza desta interdição que recai não sobre o "dizer alguma coisa", que seria uma opinião, mas sobre o "pronunciar um nome", que é pura articulação vocal. É propriamente o saber linguístico: certa palavra ou nome não deve passar pela boca. Ela é simplesmente suprimida do registro da língua, apagada do uso, não deve mais existir. Entretanto, é esta uma condição paradoxal do tabu, este nome deve ao mesmo tempo continuar a existir enquanto interdito. É assim, enquanto existente-interdito, que se deve igualmente estabelecer o nome divino, mas, do princípio ao fim, a proibição se acompanha das mais severas sanções, e é acolhida entre povos que ignoram a prática do tabu aplicada ao nome dos mortos. Isto sublinha mais fortemente ainda o caráter singular deste interdito do nome divino.

Outro fenômeno conexo à blasfêmia é o disfemismo que, ao invés de abrandar o sentido expresso pelo ato blasfematório, o intensifica sarcasticamente. Na vida real, ocorre, às vezes, uma intensificação do sentido de determinadas expressões, usadas com intenção mordaz e pejorativamente. $\mathrm{Na}$ esfera do falar torpe, servem como exemplificações perífrases construídas de modo a transmitirem cruelmente notícias relacionadas com a morte ou mesmo a doenças graves. Constitui um disfemismo a formulação linguística "bateu as botas" para dar a notícia de que alguém faleceu (ULMANN, 1967, p. 298).

Em seu estudo clássico, Nora Galli de’ Paratesi (1964) diz que o disfemismo rompe as regras de conveniência e de adequabilidade do discurso. Disfemismo e eufemismo são colocados e analisados em estreita relação com a dinâmica social, econômica, histórica e cultural em que estão inseridos. O disfemismo, ao contrário do eufemismo, caracteriza-se pela crueza e agressividade expressas nas palavras que o veiculam, mas é dependente do contexto social e histórico: o que é disfemismo em determinado período, pode não sê-lo em outra fase.

Ao abordar a questão do eufemismo, Paratesi (1964, p. 9) esclarece que "ele tem muitos pontos em comum com outros fenômenos, como a gíria e as expressões jocosas, e pode ter, além do uso comum e espontâneo que dele se faz na conversação, também 
usos conscientes como o literário." ${ }^{15}$ Aponta o motivo psicológico como diferença importante entre o eufemismo e a gíria. " $\mathrm{Na}$ base do eufemismo, encontra-se a interdição, norma interior na maioria dos casos; por trás da gíria, em vez, está a exigência prática de não fazer-se entender por alguém."16 (PARATESI, 1964, p. 9-10).

Em sua análise da interdição, essa mesma estudiosa diz que ela é a causa psicológica do eufemismo. A interdição é entendida como "a coação a não falar sobre determinada coisa ou ainda o referir-se a essa coisa com termos que the sugerem a ideia, porém sem indicá-la diretamente." ${ }^{17}$ (PARATESI, 1964, p. 17). Reportando-se ainda ao eufemismo, acrescenta que
é aquele fenômeno linguístico pelo qual algumas palavras são evitadas e substituídas por outras. A palavra eufemismo, portanto, assume aquele conjunto de manifestações linguísticas das quais a interdição é a causa psicológica. Às vezes, na linguagem comum, entende-se por eufemismo o termo que é usado no lugar daquele atingido pela interdição: nesse sentido preferiremos usar substituto eufemistico ou simplesmente substituto" ${ }^{\prime 18}$. [grifo da autora].

Em outro texto, aborda a questão do eufemismo e do disfemismo na linguagem atual e descontraída de alguns políticos italianos. Chama a atenção para a crise política ocorrida na Itália, em particular, nas últimas décadas do século passado e início deste (cf. PARATESI, 2009). A mudança de costumes políticos teve claramente reflexos na linguagem. De acordo com essa estudiosa, é evidente uma diminuição no uso de eufemismos e um uso descarado de disfemismos, que ocorrem quando, intencionalmente, uma palavra de uso normal é substituída por outra de sentido desagradável, chocante. O sentido atenuado, antes expresso pelos eufemismos, cede espaço à expressão crua num registro de linguagem popular oral. A estudiosa analisa e

${ }^{15}$ ha molti punti in comune con altri fenomeni, come il gergo e le espressioni scherzose, e può avere, oltre all'uso comune e spontaneo che se ne fa nella conversazione, anche usi consci come quello letterario (PARATESI, 1964, p. 9).

${ }^{16}$ Alla base dell'eufemismo si trova l'interdizione, norma interiore nella maggioranza dei casi, dietro il gergo invece sta l'esigenza pratica di non farsi capire da qualcuno (PARATESI, 1964, p. 9-10).

${ }_{17}$ la coazione a non parlare di una data cosa o ad accennarvi con termini che ne suggeriscano l'idea pur senza indicarla direttamente (PARATESI, 1964, p. 17).

18 è quel fenomeno linguistico per cui alcune parole vengono evitate e sostituite con altre. La parola eufemismo quindi, riassume quell'insieme di manifestazioni linguistiche di cui l'interdizione è la causa psicologica. A volte nel linguaggio comune, si intende per eufemismo il termine che viene usato al posto di quello colpito da interdizione: in questo senso preferiremo usare sostituto eufemistico o semplicemente sostituto (PARATESI, 1964, p. 17). 
mostra a grande mudança havida no âmbito social em estreita relação com as modificações linguísticas. Mais uma vez, confirma-se a variabilidade da língua, neste caso, a alteração das palavras e de seu uso através do tempo, com perda do sentido dos eufemismos e intensificação de seus contrários, isto é, os disfemismos. Paratesi (2009) assinala que também os eufemismos são afetados e sofrem alterações. Ressalta que o discurso político atual privilegiou o disfemismo inserindo-o numa linguagem menos formal, mais popular em detrimento daquela formal, predominante no passado.

\section{A blasfêmia e o turpilóquio na vida do ítalo-gaúcho}

Em nosso estudo, creditamos as blasfêmias e o comportamento do blasfemador a uma herança linguística e cultural italiana. Situamos, pois, a existência desta cultura e desta modalidade de linguagem na RCI em tempos distantes, já praticada no Velho Mundo. O Turpilóquio dos imigrantes italianos e de seus descendentes foi praticado contra Deus e contra outras divindades (caso da blasfêmia), contra o homem em sentido genérico (caso dos insultos e das imprecações), e de tantos outros modos de ofender o próximo. O falar torpe, parte integrante da cultura e da linguagem do ítalo-gaúcho, particularmente a blasfêmia, teve como suporte, em sua manifestação, a forma linguística dialetal italiana, vale dizer, sua língua materna.

A blasfêmia pode ter se atualizado, na RCI devido, devido ao sentimento de impotência do homem diante de determinadas situações difíceis como, por exemplo, o extermínio de uma inteira colheita por causa de uma chuva de granizo, ou pela passagem de um vendaval devastador. Nas comunidades rurais da RCI, fenômenos atmosféricos e catástrofes da natureza eram, frequentemente, enfrentados com palavrões e blasfêmias, alternados com preces, água benta e queima de ramos de oliveira, abençoados na Igreja por um sacerdote e guardados pelos fiéis em suas casas, para serem usados essas ocasiões. O contingente lexical do falar torpe da RCI e a prática de blasfemar e de ultrajar as divindades configuram uma contradição com o espírito religioso de fé em Deus e na igreja católica. Como tal, o estudo do turpilóquio revela-se importante, de modo particular, visto não só como segmento de palavras graves, severas, obscenas e ofensivas, mas como um fenômeno social e linguístico de 
significado próprio, típico da cultura e da vida quotidiana do grupo étnico minoritário dessa região.

Assim sendo, não só o aspecto formal do linguajar torpe do contexto bilíngue da RCI apresenta interesse (cf. FROSI, 2011), pela grande riqueza de eufemismos, figuras de retórica e cruzamentos dialetais manifestados nesses dizeres, como também o estudo do turpilóquio é relevante pelo uso peculiar de palavras torpes como marcadores linguístico-culturais do mundo vêneto-lombardo e trentino, usadas e praticadas de geração em geração na RCI (cf. FROSI; FAGGION; DAL CORNO, 2010). O fato confirma um fenômeno de fala presente não só na RCI, mas também no contexto de onde provieram os imigrantes italianos.

O contexto de nossa pesquisa é o de língua minoritária - dialetos italianos - em convívio com a língua oficial do país acolhedor, a língua portuguesa. Trata-se, portanto, de uma comunidade mista em que culturas diferenciadas estão presentes. Ao mesmo tempo em que a língua dominante, a portuguesa, vem se impondo e preenchendo com força decisiva todas as funções nos mais diferentes domínios sociais, a fala dialetal italiana permanece indissociável de vários elementos culturais da pátria de origem, apesar de ser o sistema dominado e estar em fase de extinção (cf. FROSI; MIORANZA, 2009).

As blasfêmias registradas para este trabalho situam-se na oralidade. A blasfêmia, sua prática e transmissão, acompanha a trajetória de vida dos ítalo-gaúchos, através do tempo; é um elemento marcante da cultura desse grupo humano. Com base neste entendimento, registramos as formas blasfêmias e suas variantes fonéticas e lexicais e procuramos entender os sentidos por elas expressos.

No âmbito da nova terra, em solo brasileiro, a blasfêmia foi praticada contra Deus e contra outras divindades, contra objetos e símbolos sagrados. Ela é parte integrante da cultura e da linguagem do ítalo-brasileiro que, para expressá-la, privilegia a forma de sua língua materna. Do passado ao presente, o ato de blasfemar ainda se concretiza, faz-se audível e tem suporte nas formas dialetais italianas. O estudo da blasfêmia é relevante também pelo uso peculiar de suas várias formas como marcadores linguístico-culturais inseridos e praticados no decurso rotineiro de todos os dias. 


\section{As formas básicas da blasfêmia e as formas eufêmicas}

A lista das unidades de blasfêmias registradas em nossa pesquisa é relativamente pequena, se considerarmos as formas básicas, ou fixas. Contudo o mesmo não acontece com as formas blasfematórias, variantes usadas como eufemismos que são, de fato, bastante numerosas.

Classificamos as formas básicas, distinguindo-as de outras mascaradas ou camufladas em seu aspecto fonético e lexical. Denominamos eufemismos as formas variantes usadas com intuito de atenuar o caráter vulgar e ofensivo de algo que se quer transmitir sem, todavia, passar por vilão. A propósito disso, a locução eufêmica "Pòrco Zio"19 (= porco tio), constante no material desta pesquisa, contém a palavra interdita "Dio" que não é articulada, não é atualizada, é, porém virtual, está subjacente à forma lexical "zio" que, por sua vez, está explicitada. Embora com menos transparência, encaixam-se também nessa análise outras locuções da amostra, tais como: "Co Dìona", "Co Zìona", "Òrco Dìoseli”, "Pòrco Dìona", "Pòrco Zìone”. Essas locuções eufêmicas estão mais bem mascaradas do que a primeira analisada. Nas duas locuções eufêmicas "Co Dìona" e "Co Zìona", a palavra "pòrco" foi reduzida à sílaba "Co" e o nome "Dio" (= Deus) está representado pela forma alterada, respectivamente, em "Dìona" e "Zìona". Um processo semelhante ocorre com as locuções "Òrco Dìoseli", "Pòrco Dìona" e "Pòrco Zìone". Aqui, observa-se outra variante eufêmica para a palavra "pòrco", isto é, "Òrco". O segundo elemento dessas três locuções blasfêmicas é representado, respectivamente, por "Dioseli", "Dìona" e "Zìone", todas elas substituindo a palavra "Dio" (=Deus).

Na locução "Pòrca Madònega", é a forma feminina "Madònega", substituta de "Madona" (=Nossa Senhora) que consagra o eufemismo. Outros exemplos, representados por uma palavra apenas, como "Madòsca", "Madunara" e sequências similares, dão vida ao mesmo processo eufêmico que, aliás, vai se repetindo com a palavra "Sacramento" que foi atualizada pelas variantes "Cramegna", "Mento", Sacra Pìtole".

${ }^{19} \mathrm{O}$ acento grave, em palavras dialetais italianas, indica, neste texto, abertura do timbre da vogal. 
$\mathrm{Na}$ amostra desta pesquisa, destacamos uma blasfêmia que classificamos como disfemismo. Na blasfêmia "Dio Negro", é dado a Deus um atributo que ele não possui. No contexto sociocultural da RCI, essa blasfêmia é densamente carregada de sentido negativo.

Dentre os contextos sociais e de trabalho observados na produção das blasfêmias, destacamos quatro por eles terem se mostrado mais propícios e fecundos, na recorrência de atualizações orais das blasfêmias. São eles: (a) durante o jogo de cartas, de modo geral, nos encontros na bodega, em dias de festas, ou em fins de semana; (b) nas partidas de futebol, assistidas diretamente no campo onde se realiza o jogo, ou através da televisão; (c) na labuta do trabalho quotidiano, ou diante de intempéries da natureza; (d) nos desentendimentos, nas discussões e brigas com alguém por motivos diversos (cf. FROSI, 2011).

Nos contextos compreendidos nos itens "a" e "b", a produção das blasfêmias dáse de modo semelhante, ou idêntico. O motivo propulsor é o mesmo: sentimentos de euforia ou de vitória podem ser acompanhados de blasfêmias face ao sucesso, ou ainda, explosões de raiva, furor, ira e decepção marcam irremediáveis derrotas.

Nas situações atinentes ao item “c”, as blasfêmias decorrem, na maioria das vezes, como manifestação de sentimentos de pequenez e de impotência dos homens em dar solução a problemas cruciais que afetam sua incapacidade de resolvê-los. Vale lembrar, como exemplo, uma chuva de granizo que, em poucos minutos, destrói toda a uva que estava prestes a ser colhida. Ao serem solicitados a darem uma explicação sobre os motivos que levam as pessoas a proferirem blasfêmias, os sujeitos das entrevistas foram unânimes em afirmar que dizem blasfêmias porque se sentem completamente incapazes de resolver ou superar essas situações. A explicação dada pelos sujeitos da pesquisa assemelha-se à descrição feita por Cesare Pavese (1973), referentemente à blasfêmia proferida por um indivíduo que possui e professa sua fé em Deus.

A blasfêmia pode ter significados diversos, dependendo de quem a pronuncia seja um crente ou um não crente. Se é um crente, a tradução da blasfêmia poderia ser: "Deus, me negligenciaste e agora me vingo 
para me desabafar e obter a tua atenção" ${ }^{20}$ (apud TARTAMELLA, 2006, p. 17).

Para os sujeitos desta pesquisa é como se fosse proferida uma lamentação dirigida a Deus que parece estar ausente ou alheio ao infortúnio destruidor da própria natureza. O fato nos sugere uma grande intimidade do blasfemador para com Deus. Depreende-se dos argumentos apresentados pelos sujeitos que a blasfêmia escapa de sua boca, quase como uma súplica a Deus, impregnada de desespero. Afinal, perdendo a colheita da uva ou a de outra plantação, perdido fica o alimento juntamente com um ano de árduo e penoso trabalho. Sua expectativa em relação aos meses sucessivos é de vida difícil de situação perigosa. A ameaça do fantasma da fome, realidade vivida na terra de origem por seus ancestrais, tem de ser banida nem que seja à custa de algumas blasfêmias reveladoras de desespero.

No que concerne ao item "d", blasfêmias, mescladas com outros palavrões, são impulsivamente descarregadas em réplicas sucessivas, com alternância entre adversários em situação de contenda. Blasfềmias, palavras torpes e brutais, com frequência, fazemse acompanhar de socos e pancadas (cf. FROSI, 2011). Uma questão extremamente séria que ensejava briga acompanhada de blasfêmias e palavras torpes, de agressões morais e físicas, era e é a do desrespeito, de invasão da propriedade. Um estudo inédito $^{21}$ apresentou resultados dignos de reflexão. A pesquisa, desenvolvida com base em documentos escritos, revelou que o maior número de homicídios cometidos no passado, na RCI, tinha como causa fatos relacionados com a propriedade de habitantes ítalo-brasileiros como, por exemplo, o deslocamento dos marcos que separam um terreno do outro e estabelecem os limites de ambos. Compreende-se, de certo modo, a ocorrência deste ato horrendo, se for lembrado que o grande objetivo do imigrante, ao ter de abandonar sua pátria na busca de outra que lhe era desconhecida, era o de tornarse proprietário de um lote de terra rural.

As unidades básicas foram consideradas, neste trabalho, formas interditas, isto é, aquelas que, segundo Benveniste (ver citação atrás), não devem ser pronunciadas. A

${ }^{20}$ La bestemmia può avere significati diversi a seconda che chi la pronuncia sia un credente o un non credente. Se è un credente, la traduzione della bestemmia potrebbe essere: "Dio, mi hai trascurato e ora mi vendico per sfogarmi e ottenere la tua attenzione” (PAVESE, apud TARTAMELLA, 2006, p. 17).

${ }^{21} \mathrm{O}$ estudo foi realizado por estagiários do curso de Direito, sob a orientação do professor, juiz Dr. Marino Kury, na década de oitenta. 
carga ofensiva aparece atenuada e dissimulada em várias formas eufêmicas. Usamos a palavra eufemismo para referirmo-nos às expressões e aos nomes que substituem ou acompanham aqueles interditos, usados com finalidade de abrandar a injúria.

Em nossa listagem, apesar de se contarem em menor número, algumas palavras e locuções interditas de blasfêmias foram plenamente realizadas a nível fonético, lexical e a nível morfossintático. São expressões fixas que acreditamos tenham sido herdadas como hábitos praticados em terras distantes, desde tempos remotos. Ilustram essa afirmação as blasfêmias: Pòrco Dìo, Pòrca Madòna, Dìo Pòrco, Dìo Cane, Gesù Pòrco, Pòrca Òstia, Sacramento.

Sem dúvida, o maior número é contemplado pelos eufemismos que atenuam a ofensa e a injúria aos entes divinos a que são dirigidas e tornam menos chocante a profanação dos objetos sagrados. Com o uso de eufemismos, parece que o autor da blasfêmia fica menos exposto em sua incivilidade, menos agressivo em sua explosão raivosa, semiencoberto em seu provável sentimento de culpa. É como se a ofensa feita através de eufemismos envolvesse alguma perspicácia, para não dizer astúcia em sua formulação, ou então covardia do blasfemador. Vistas desse modo, as variantes blasfematórias revelam, além de um abrandamento da ofensa, uma riqueza vocabular, ainda que notoriamente ímpia, nefanda e chocante - um sinal de criatividade e, embora questionável, também pode ser vista como polidez ou fraqueza do blasfemador. Ao serem analisadas, as formas eufêmicas evidenciam sua pertença ao léxico, exatamente como elementos inovadores da língua porque novos elementos lexicais que substituem as palavras interditas são criados e introduzidos conforme o momento histórico, social e cultural.

Transcrevemos, a seguir, uma parte do universo das blasfêmias e dos eufemismos coletados na pesquisa. Optamos por transcrever as palavras ou locuções blasfematórias preservando-as nas suas formas tal e quais foram realizadas pelos sujeitos da amostra.

\begin{tabular}{|l|l|}
\hline Formas básicas & Variantes usadas como eufemismos \\
\hline $\begin{array}{l}\text { Pòrco Dìo, Dìo Madòna, } \\
\text { Madona Dìo, Dìo Santa Òstia, } \\
\text { Cristo Dìo, Dai Dìo Pòrco, Dìo }\end{array}$ & $\begin{array}{l}\text { Co Dìo, Co Dìona, Co Zìo, Co zìona, Cristòfuli, Dìo de una Mama, Dìol, Dìol Fiol d'un Can, Dìo Madònega, Dìo Poldo, Dìo } \\
\text { Porcana, Òrco Dìo, Òrco Dìoseli, Pòrco Bèstia, Pòrco Can, Pòrco }\end{array}$ \\
\hline
\end{tabular}




\begin{tabular}{|l|l|}
\hline $\begin{array}{l}\text { Can, Dìo Vaca, Dìo Pòrco, Dìo } \\
\text { Cane, Pòrco Santo, Pòrco } \\
\text { Sacramento, Dio Cristo, Dìo } \\
\text { Putana, Gesù, Gesù Pòrco, Ma } \\
\text { Dìo, Dìo Negro. }\end{array}$ & $\begin{array}{l}\text { Cane, Pòrco Dìna, Pòrco Dìone, Pòrco Due, Pòrco Fumo, Pòrco } \\
\text { Zione, Zio Bèrghena, Zòrco Mio, Pòrco Stùpido, Pòrco Zio, Pòrco } \\
\text { Pòrcchi, Zio Pòrco, Zio Putìn. }\end{array}$ \\
\hline Pòrca Madona & $\begin{array}{l}\text { Madòna de la Carupita, Madòna de la Corrupta, Madòna Vìrgola, } \\
\text { Madónega, Madòsca, Madunara, Órca Madòna, Pòrca Canèla, Pòrca } \\
\text { Malora, Pòrca Mastèla, Pòrca Miséria, Pòrca Pipa, Pòrca Pistòla, Pòrca } \\
\text { Putana. }\end{array}$ \\
\hline Sacramento, Santo Sacramento. & $\begin{array}{l}\text { Cramegna, Megna, Mento, Sacramegna, Sacramenta, Sacrament, } \\
\text { Sacranon, Sacra Pél, Sacra Pipa, Sacra Pìtole. }\end{array}$ \\
\hline Sacra Òstia, Òstia, Òs-cia & Can del'Òstrega, Òstrega. \\
\hline
\end{tabular}

\section{A blasfêmia e a religião católica no contexto da RCI}

A pertença à Igreja Católica e a prática dessa religião, a crença em Deus, em Nossa Senhora e nos santos, em geral, a fé, tudo isso norteou a vida dos ítalo-brasileiros da RCI. A família assim constituída, católica e praticante, reproduziu-se na nova pátria em conformidade com o modelo originário existente no Norte da Itália. Ensinados e instruídos pelos pais, os filhos passaram a seus descendentes a doutrina e os princípios da fé e da religiosidade católica com os quais se identificaram e ainda se identificam. (FROSI, FAGGION, DAL CORNO 2006, p. 102-103).

Defensores do crédito católico, apostólico, romano e praticantes dessa religião eram as famílias de imigrantes italianos que se estabeleceram na área territorial, especificamente, nos lotes de terra predestinados a eles. Inúmeros estudiosos analisaram e escreveram sobre este assunto, dentre eles, Sabbatini, 1975; Frosi e Mioranza, 1975 e 2009; Azevedo, 1975; De Boni; Costa, 1979; De Boni, 1980; Merlotti, 1979.

A filiação à Igreja Católica dos ítalo-descendentes e sua persistência na prática dessa religião contam com uma tradição secular. Assim eram seus ancestrais na Itália e, reproduzindo esse modelo de fé cristã, deram prosseguimento à tradição originária. Formaram suas famílias e construíram suas comunidades na RCI, mantendo, por mais de um século, sua fala dialetal, a hierarquia familiar seu credo e sua dedicação ao trabalho. Foram persistentes também na prática da blasfêmia e do turpilóquio. A religião católica e a prática da blasfêmia parecem duas coisas antagônicas. A ambivalência compreende dois aspectos diversos, não necessariamente contraditórios. A blasfêmia ofende a Deus, mas supõe do blasfemador certa familiaridade, uma grande 
proximidade em relação a ele. No exercício do bem ou na obra do mal, só se consegue efetivamente atingir quem está próximo. Malgrado a fé em Deus, em Nossa Senhora, na devoção aos santos e no respeito às coisas sagradas, a blasfêmia foi partícipe do tempo de vida dos habitantes da RCI. Pelo que se sabe, não houve quebra desta atividade linguística e cultural nessa região, mesmo sendo a blasfêmia considerada pecaminosa pela igreja e pelos seus fiéis servidores, ministros de Deus. A prece e a blasfềmia estiveram juntas no mesmo tempo e lugar, na boca de um mesmo indivíduo. A conciliação entre o blasfemar e o acreditar em Deus exigia uma intermediação, a prece. Segundo Tartamella (2006, p. 308), por meio da prece é restabelecido o vínculo com Deus. E acrescenta: "Também a prece é uma palavra "mágica" (permite a comunicação com um Ser transcendente, intangível, invisível." ${ }^{22}$ Nas comunidades em que se realizou a pesquisa, a prece tinha o poder de reverter para a comunhão de graça o estado de pecado, originado por uma ofensa grave feita a Deus através da blasfêmia. A prece, porém, tinha essa valia quando determinada por um sacerdote, mediante confissão do pecado cometido. A confissão compreendia a declaração verbal feita ao ministro de Deus, o arrependimento sincero do penitente que era, então, absolvido, cumprindo a penitência imposta. Desse modo, a graça e o pecado alternavam-se no âmbito da consciência e da alma. A vida prosseguia em paz e harmonia até quando, inequivocamente, novas blasfêmias eram proferidas.

$\mathrm{O}$ instrumento construído e usado na pesquisa de campo continha questões finalizadas à obtenção de informações sobre por que os ítalo-gaúchos blasfemavam e ainda blasfemam. Intencionava-se obter alguma explicação sobre estes atos abomináveis pronunciados em alta voz, não poucas vezes, com sentido aumentado pelos gestos das mãos e semblantes enrubescidos. Os resultados esclarecem que:

os blasfemadores, não tinham e não têm intenção consciente e explícita de ofender a Deus: trata-se de uma explosão verbal, de uma descarga emotiva, provocadas pela própria impotência em resolver algum problema. Todos os sujeitos negaram terem eles a intenção de injuriar a Deus e a outras divindades. Descrito por eles próprios, o ato de blasfemar é um desafogo, um impulso incontrolado, causado pela fragilidade humana, no caso, entendida e vivenciada por eles como não assistida por Deus naquele momento crucial de fraqueza, face a

${ }^{22}$ Anche la preghiera è una parola "magica" (permette la comunicazione con un Essere trascendente, intangibile, invisibile) (TARTAMELLA, 2006, p. 308). 
problemas difíceis, às vezes impossíveis, de serem resolvidos. Tratase de estados de espírito confusos, cheios de tristeza, de raiva, de dor, de desamparo, de desespero, de abandono (FROSI; FAGGION; DAL CORNO, 2010).

Mesmo assim, como ato sucessivo, não faltavam (e não faltam) o remorso e sentimentos de culpa. A confissão ao ministro de Deus e sua absolvição devolvia a eles a paz de espírito, a graça e o bem-estar com o sagrado, com Deus e com outras divindades. A confissão e a absolvição, seguidas de penitências, não pequenas em tempo de rigorosa pressão da igreja, na RCI, séculos XIX e XX, garantiam por algumas horas, um retorno ao confortável âmbito da fé católica. Isso, contudo, não perdurava: a blasfêmia constituía (e ainda é) um hábito, uma atitude com repetições constantes, um componente ativo, pode-se dizer, quase rotineiro, na vida dos habitantes das comunidades rurais.

Os dados registrados na pesquisa revelam uma diminuição no uso da blasfêmia no presente. Sua prática era mais expressiva no passado, uma presença marcante em termos de frequência e em número de indivíduos que a praticavam. As comunidades eram, então, tipicamente rurais. A vida dura e difícil não permitia a seus habitantes tempo algum para a distração e o lazer. A vida se resolvia por obra de muita luta, com trabalho pesado e intenso suor.

As pessoas mais simples referiam-se, frequentemente, à prática de blasfemar com a expressão "o vício de blasfemar". Os sujeitos urbanos da amostra, de modo geral, têm conhecimento das várias formas da blasfêmia e alguns deles, eventualmente, ainda as praticam, a maioria não. De fato, ouvir uma blasfềmia, num café, num restaurante, numa praça, ou andando pelas ruas da cidade, é algo bastante raro. Nas cidades, os contextos propícios à blasfemação são bastante limitados. Um motivador especial, que ainda leva à produção de blasfêmias, é a partida de futebol (DAL CORNO; FAGGION, 2011, p. 173-176). Mesmo durante o jogo, as desavenças e brigas são acompanhadas por palavrões; a blasfêmia cede lugar a outras expressões insultuosas, às vezes, de baixo calão, hostis, obscenas, - usando uma grafia que espelha uma linguagem popular, descontraída - por exemplo, a frase Vai tomá no cu! Diferentemente do que se constata na produção de blasfêmias, que sempre são ditas em dialeto italiano, a maior parte das palavras indecorosas, vulgares, chulas, são proferidas em português. 
No caso dos sujeitos urbanos, o fenômeno do enfraquecimento do vício de blasfemar encontra explicação, dentre outros, em dois fatores: (a) a anulação do dialeto italiano em benefício da língua portuguesa; (b) o enfraquecimento da fé em Deus, a incredulidade da existência de outra vida após a terrena e a inobservância das normas e deveres do catolicismo.

Nos centros urbanos maiores, raramente, se ouve falar em dialeto italiano. Vimos, acima, que a blasfêmia, na RCI, sempre teve como suporte linguístico o dialeto italiano. A anulação progressiva da fala dialetal italiana leva consigo também as formulações da blasfêmia. Obviamente, não lamentamos o enfraquecimento da prática da blasfêmia como ultraje, mas, como perda, no sentido de que é mais um sintoma da anulação da cultura tipicamente italiana. Esse sintoma é evidente em outros segmentos da oralidade do dialeto. Constata-se, por exemplo, a anulação de ditos e provérbios dialetais italianos que são fórmulas de sabedoria popular, incluindo ainda as canções de ninar e as filastrocche que consistem em uma sucessão longa de palavras, com ritmo cadenciado, comumente em versos.

O segundo fator influente na extinção da blasfêmia, nos centros urbanos das cidades pesquisadas, pode ser atribuído ao enfraquecimento do culto da religião católica dos ítalo-descendentes. A intimidade e familiaridade com Deus, com Nossa Senhora e com os santos sofreram um processo de diminuição. $\mathrm{O}$ distanciamento com o sagrado conduziu a um esmorecimento do vício de blasfemar. O ateu, levando a questão ao extremo, não tem alvo a quem dirigir o ultraje e, portanto, não tem Deus para profanar. É bem verdade que, como diz Tartamella, o ateu, quando blasfema, não ofende a Deus e, sim, às pessoas que acreditam em Deus. Acrescenta ainda: “Com rigor de lógica, um ateísta não deveria blasfemar: as blasfêmias não negam Deus, mas afirmam a existência dele como destinatário de um insulto",23 (2006, p. 17).

Além disso, é interessante considerar que o ítalo-descendente dos centros urbanos da RCI, muito mais do que o das comunidades rurais, vem sofrendo um processo de intensa aculturação com as tradições gaúchas e brasileiras. Não temos conhecimento de blasfêmias ditas em português, na RCI. Concluindo esta questão, há

${ }^{23}$ A rigor di logica, un miscredente non dovrebbe bestemmiare: le bestemmie non engano Dio, ma ne affermano l'esistenza come destinatário di un insulto (TARTAMELLA, 2006, p. 17). 
uma evidência de que a blasfêmia, como elemento linguístico e cultural, acompanha o processo irreversível de anulação da cultura e do dialeto italiano.

\section{A blasfêmia na RCI: a questão de gênero e a faixa etária}

A palavra gênero é aqui usada para fazer referência ao comportamento social e cultural que se manifesta no relacionamento entre homens e mulheres na vida em comunidade, no presente caso, nas comunidades da RCI. Os dados desta pesquisa mostram que o vício de blasfemar, embora não exclusivamente, reflete um fenômeno do gênero masculino. Na pesquisa realizada, não foram ouvidos todos os habitantes dos três municípios (seria um número demasiadamente grande), mas os sujeitos entrevistados afirmaram que todos os homens blasfemam e que somente algumas mulheres o fazem. É válido, também para a questão de gênero, o que se afirmou acima a respeito da oposição urbano/rural.

Nas comunidades rurais, a prática da blasfêmia não é um comportamento exclusivo dos indivíduos adultos de gênero masculino, também os jovens blasfemam. Poucas são as mulheres afeitas a esse vício de blasfemar; algumas delas, todavia, compartilham deste comportamento que é mais peculiar ao gênero masculino. Atribuímos esta diferença entre o gênero masculino e o feminino à própria situação da mulher nas comunidades rurais, limitada, em geral, a trabalhos domésticos, considerados economicamente pouco importantes pela sociedade em que se inserem. Muito mais do que aos homens, cabe às pessoas de gênero feminino um papel marcante na educação dos filhos. Além disso, pesa, especialmente, sobre as mulheres a responsabilidade de assegurar a harmonia da família, no interior da própria casa e do pequeno grupo.

A cisão que separa homens e mulheres no mercado de trabalho tem raízes profundas, goza de uma tradição milenar. Não seriam as diferenças de sexo as únicas responsáveis por essa dicotomia. Naturalmente, a situação da mulher ítalo-gaúcha e os papéis por ela desempenhados são resultantes de um processo histórico-cultural que atribuiu determinados direitos aos homens e os negou às mulheres. A desigualdade existiu e, respeitadas as proporções, hoje atenuadas, ainda perdura com alguns benefícios a mais para o homem. A própria mulher interiorizou a idéia de ser social e 
economicamente inferior ao homem e assim se comportou por muito tempo. Obviamente, não se trata aqui de defender o direito de a mulher blasfemar, mas de assinalar que também esta prática é social e culturalmente construída, seus traços característicos, preservados através do tempo e dos lugares, são até hoje transmitidos às gerações sucessivas às dos ancestrais italianos da RCI. Quando, na fala de pessoas do gênero feminino, ocorre a produção de blasfêmias, o fenômeno é visto como feio, grosseiro, rude, comprometedor, em síntese, um comportamento que depõe contra a própria feminilidade, assim entendida, de modo geral, pelos próprios blasfemadores. $\mathrm{O}$ vício de blasfemar sempre foi um elemento linguístico-cultural típico do gênero masculino. A condição de vida feminina era de submissão, de dependência, de obediência ao chefe da família cuja função de autoridade era, normalmente, tributada ao marido. A educação dos filhos, o acompanhamento deles desde o nascimento, era papel central da mulher. Era seu dever incutir-lhes princípios de bom comportamento, de doutrina católica e, sobretudo, de respeito e obediência às pessoas hierarquicamente superiores na estrutura familiar.

Também no caso das crianças, havia uma distribuição de papéis em conformidade com seu gênero e de acordo com sua idade. Os meninos aprendem a blasfemar, desde cedo, como decorrência do processo de imitação propiciado pelos mais velhos na convivência quotidiana, como auxiliares em atividades e trabalhos mais rústicos. Eles, por um convívio maior do que o das meninas com as pessoas de gênero masculino, começam, desde cedo, a aprender as atividades desenvolvidas pelas pessoas de seu sexo, reproduzindo seus hábitos e costumes, inclusive o de proferir palavrões e blasfêmias. As meninas engajam-se nas tarefas da casa, juntamente com a mãe. A figura da mãe devia e deve ser imitada por elas e, de igual modo, aprendem a reproduzir as atividades praticadas por ela. $\mathrm{O}$ ato de blasfemar não era e não é condizente com a função da mulher. Mesmo assim, embora não seja a norma geral, há mulheres que blasfemam. No caso do gênero masculino, o ato de blasfemar, além do que já foi dito, assume uma conotação de masculinidade, de força e superioridade machista, de autoridade.

\section{Considerações finais}


Retomando a análise efetuada, destacamos alguns dos resultados a que chegamos. A carga ofensiva da blasfêmia está em correlação com a intensidade da fé e do credo do blasfemador. No passado, na vida do ítalo-descendente, uma fé católica inabalável contrastava com uma ofensa radical a Deus. Na atualidade, constata-se, na RCI, um distanciamento do homem em relação a Deus, às divindades, aos símbolos sagrados. Há uma diminuição da fé e da frequência à prática religiosa. Dá-se, em parte, um esvaziamento da carga semântica da blasfêmia. Todavia, pode-se afirmar que, no passado e no presente, respeitadas as devidas proporções, a blasfêmia foi e é praticada, concomitantemente, como ofensa e como marcador de fala.

À medida que os povoados foram se transformando em centros urbanos, houve uma diminuição progressiva da prática da blasfêmia. Nesse mesmo contexto, o bilinguismo de dialeto italiano e português foi gradativamente se resolvendo em monolinguismo português. A blasfêmia não assumiu $\mathrm{o}$ aspecto formal da língua portuguesa e está sendo anulada como elemento cultural e linguístico tipicamente italiano. Em poucas palavras, o ítalo-gaúcho das comunidades rurais da RCI e dos pequenos centros urbanos sempre blasfemou e ainda blasfema em oposição aos falantes dos centros urbanos mais desenvolvidos social e economicamente que, aos poucos, foram se adaptando à cultura e à língua portuguesa. Embora ainda conheçam as blasfêmias dialetais italianas, praticam-nas em menos contextos e em menor número. Este estado atual encontra uma razão explicativa na própria miscigenação linguística e cultural constatável nos centros urbanos, ao contrário de uma relativa preservação de hábitos e de linguagem verificáveis nas comunidades rurais. Os dados da pesquisa deixam evidente que o blasfemador típico é rural, provavelmente, porque a fala dialetal italiana ainda é vigente na área rural, embora também aí predomine a língua portuguesa.

A blasfềmia, na RCI, constitui-se num elemento linguístico-cultural peculiar do grupo étnico italiano local. Os resultados da pesquisa mostram que, em áreas limítrofes com as de colonização alemã como, por exemplo, Alto Feliz, Salvador do Sul, Vale do Taquari, Vila Cristina, no Vale do Rio Caí, a blasfêmia foi assimilada e é usada na forma dialetal italiana também pelos germânicos. As formas blasfemas, em alguns casos, foram adaptadas a traços fonéticos dos dialetos alemães. Exemplificam tal pronúncia, formas como "Porco Tio", em vez de "Pòrco Dìo" ou "Pòrca Matòna", em vez de "Pòrca Madòna" em que a consoante oclusiva dental sonora /d/, em ambas as 
blasfêmias, é realizada como oclusiva dental surda na fala de alguns alemães observados na pesquisa (cf. FROSI, 2011).

Outro fato verificado foi o de que, nos casamentos entre alemães e italianos ou nos de seus descendentes, o cônjuge alemão aprende e diz blasfêmias em dialeto italiano, o inverso não foi constatado. Observamos que a blasfêmia tem como suporte formal o dialeto italiano. Os demais segmentos do turpilóquio são representados com alternância do dialeto italiano e da língua portuguesa, com maior incidência para essa.

Enfim, as reflexões que fizemos não foram suficientes para darem uma resposta à nossa pergunta inicial, isto é, por que os italianos e seus descendentes blasfemam. Parece-nos pouco sólida a explicação de que fazem isso porque se sentem impotentes de resolver determinados problemas em situações cruciais. De igual forma, somos levados a questionar até que ponto a prática da blasfêmia se justifica como desafogo, expressão de raiva, etc. O tema, ao término da pesquisa, mostra-se bem mais complexo e instigante do que se supunha. Nosso interesse cresce e acreditamos que somente um estudo multidisciplinar, talvez, centrado na neurolinguística, venha a produzir resultados e explicações mais abrangentes.

\section{Referências bibliográficas}

AQUINO, Tomás de. Suma teológica - Volume V. In: COSTA, Rovílio; DE BONI, Luís A. Porto Alegre: EST; Sulina; Caxias do Sul: EDUCS, 1980.

AZEVEDO, Thales de. Italianos e gaúchos: os anos pioneiros da colonização italiana no Rio Grande do Sul. Porto Alegre: Iel, 1975.

BENVENISTE, Émile. Problemas de Linguística Geral II. 2.ed. Campinas: Pontes, 2006.

BOERIO, Giuseppe. Dizionario del dialetto veneziano. Edição Fac-similar da obra publicada em 1856 por Giovanni Cecchini Edit., Firenze: Giunti, 1993.

BURKE, Peter. A arte da conversação. Traduzido por Álvaro Luiz Hattnher. São Paulo: UNESP, 1995. 
CAPUANO, Romolo Giovanni. Turpia: sociologia del turpiloquio e della bestemmia. Milan: Costlan, 2007.

CORTELAZZO, Manlio; ZOLLI, Paolo. Dizionario etimologico della lingua italiana. 5 vol. Bologna: Zanichelli, 1988.

CUNHA, Antônio Geraldo da. Dicionário etimológico Nova Fronteira da língua portuguesa. Rio de Janeiro: Nova Fronteira, 1982.

DACANAL, José H. (Org.). RS: imigração e colonização. Porto Alegre: Mercado Aberto, 1980.

DAL CORNO, Giselle Olivia Mantovani. Consequências de atitudes linguísticas negativas em grupos linguísticos: da estigmatização à solidariedade. In: FROSI, Vitalina Maria; FAGGION, Carmen Maria; DAL CORNO, Giselle Olivia Mantovani. Estigma: cultura e atitudes linguísticas. Caxias do Sul: EDUCS, 2010, p. 77-97.

DAL CORNO, Giselle Olivia Mantovani; FAGGION, Carmen Maria. Turpilóquio: uso geral e insultuoso. In: Revista Domínios de Lingu@gem. v. 5, n. $2-2^{\circ}$ Semestre 2011 - Disponível em: http://www.seer.ufu.br/index.php/dominiosdelinguagem/article/view/13727/8161. Acesso em: 24 de janeiro de 2012 .

DE BONI, Luís Alberto. $\mathrm{O}$ catolicismo da imigração: do triunfo à crise. In: DACANAL, J. H.; GONZAGA, S. (Orgs.). RS: Imigração e Colonização. Porto Alegre: Mercado Aberto, 1980.

DE BONI, Luís Alberto; COSTA, Rovílio. Os italianos do Rio Grande do Sul. Porto Alegre: EST e Caxias do Sul: EDUCS, 1979).

DEVOTO, Giacomo di; OLI, Gian Carlo. Il dizionario della lingua italiana. Firenze: Le Monnier, 1990.

DOGO, Leone. Bestemmia vergogna d'Italia: Italiano, perché bestemmi? Cristiano, perché taci? Padova: Carroccio, 1986.

DURANTI, Alessandro. Antropologia del linguaggio. Roma: Meltemi, 2002.

FAGGION, Carmen Maria. Persistência de uma língua no turpilóquio. In: HORA, Dermeval da (Org.). Anais do VI Congresso Internacional da ABRALIN. João Pessoa, PB: Ideia, 2009, p. 635-641. 
FAGGION, Carmen Maria. Bilinguismo e cultura. In: Conjectura, v. 11, n. 1, p. 123139, jan.jun. Caxias do Sul, RS: EDUCS, 2006, p. 123-139.

FAGGION, Carmen Maria. Bilinguismo precoce e estigma. In: GIRON, Loraine Slomp; RADÜNZ, Roberto (Orgs.). Imigração e Cultura. Caxias do Sul: EDUCS, 2007, p. 129-140.

FAGGION, Carmen Maria. Bilinguismo e cultura. In: FROSI, Vitalina Maria; FAGGION, Carmen Maria; DAL CORNO, Giselle Olivia Mantovani. Estigma: cultura e atitudes linguísticas. Caxias do Sul: EDUCS, 2010, p. 99-120.

FROSI, Vitalina Maria. Provérbios dialetais italianos; uma linguagem em extinção. Porto Alegre: 1989. 244p. Dissertação (Mestrado em Lingüística Aplicada), Pontifícia Universidade Católica do Rio Grande do Sul.

FROSI, Vitalina Maria. Bilinguismo de português e dialetos italianos: nossa história, nossa língua, nossa origem. In: GIRON, Loraine Slomp; RADÜNZ, Roberto (Orgs.). Imigração e Cultura. Caxias do Sul: EDUCS, 2007, p. 143-152.

FROSI, Vitalina Maria. Etnicidade, língua e identidade/Etnicità, lingua e identità. In: Conjectura: filosofia e educação. v. 13, n.2, jul./dez. 2008. p. 127-151.

FROSI, Vitalina Maria. Muore il dialetto, sussiste la bestemmia. In: MARCATO, Gianna, (a cura di), Le nuove forme del dialetto. Padova: Unipress, 2011, p. 311-316. FROSI, Vitalina Maria; FAGGION, Carmen Maria; DAL CORNO, Giselle Olivia Mantovani. Bilinguismo, identidade étnica e atitudes linguísticas. In: CHAVES, Flávio Loureiro; BATTISTI, Elisa (Org.). Cultura Regional: língua, história, literatura. Caxias do Sul: EDUCS, 2006, p. 97-111.

FROSI, Vitalina Maria; FAGGION, Carmen Maria; DAL CORNO, Giselle Olivia Mantovani. Prestígio e Estigmatização: Dialeto italiano e língua portuguesa da Região de Colonização Italiana do Nordeste do Rio Grande do Sul. In: Revista da ABRALIN, v. 7, número 2, Jul./Dez. 2008, p. 139-167.

FROSI, Vitalina Maria; FAGGION, Carmen Maria; DAL CORNO, Giselle Olivia Mantovani. Turpilóquio: insulto e blasfêmia. Comunicação oral, apresentada no III SIMPÓSIO INTERNACIONAL e XI FÓRUM DE ESTUDOS ÍTALO-BRASILEIROS - 135 ANOS DE IMIGRAÇÃO ITALIANA NO RIO GRANDE DO SUL, realizado na Universidade de Caxias do Sul, em 2010.

FROSI, Vitalina Maria; MIORANZA, Ciro. Imigração Italiana no Nordeste do Rio Grande do Sul: processos de formação e evolução de uma comunidade ítalo-brasileira. Porto Alegre: Movimento e Caxias do Sul: EDUCS, 1975. 
FROSI, Vitalina Maria; MIORANZA, Ciro. Imigração Italiana no Nordeste do Rio Grande do Sul: processos de formação e evolução de uma comunidade ítalo-brasileira. 2.ed. rev. e aum. Caxias do Sul: EDUCS, 2009.

GARRIOCH, David. Insultos verbais na Paris do século XVIII. In: BURKE, Peter e PORTER, Roy (Orgs.). História social da linguagem. São Paulo: UNESP, 1997.

GRECO, Giovanni. La bestemmia come rivolta: una riflessione metodologica. Salerno: EDISUD, 1994.

HÄRIN, Bernhard. A lei de Cristo: teologia moral. v. II. São Paulo: Herder, 1960.

KRAMSCH, Claire. Language and culture. Oxford: Oxford University Press, 1998.

MERLOTTI, Vania Beatriz Pisani Merlotti. O mito do padre entre descendentes italianos: a comunidade de Otávio Rocha. 2.ed. Porto Alegre: EST; Caxias do Sul: Universidade de Caxias do Sul, 1979.

HOUAISS, Antônio. Dicionário Houaiss da língua portuguesa. Rio de Janeiro: Objetiva, 2001.

JAKOBSON, Roman. Linguística e comunicação. São Paulo: Cultrix, 1969.

MARTELOTTA, Mário Eduardo (Org.). Manual de linguística. São Paulo: Contexto, 2008.

MERLOTTI, Vania Beatriz Pisani. O mito do padre entre descendentes italianos: a comunidade de Otávio Rocha. Porto Alegre: EST, 1979.

PARATESI, Nora Galli de'. Eufemismo e disfemismo nel linguaggio politico e nell'italiano di oggi. In: Synergies Italie n. spécial - 2009, p. 137-144. Disponível em: http://ressources-cla.univ-fcomte.fr/gerflint/Italie-special/nora.pdf. Acesso em: 30 de maio de 2012.

PARATESI, Nora Galli de'. Semantica dell'eufemismo: l'eufemismo e la repressione verbale con esempi tratti dall'italiano contemporaneo. Torino: Giappichelli, 1964.

PAVESE, Cesare. Il mestiere di vivere: diário 1935-1950. Torino: Einaudi, 1973. 
PINKER, Steven. Do que é feito o pensamento: a língua como janela para a natureza humana. São Paulo: Companhia das Letras, 2008.

SABBATINI, Mario. La Regione di Colonizzazione Italiana in Rio Grande do Sul: Gli insediamenti nelle aree rurali. Firenze: Cultura, 1975.

SCANELLO, Cristoforo. Elogio della bestemmia: breve trattato sulla blasfemia a [...] e dintorni. Genova: Annexia, 2004.

TARTAMELlA, Vito. Parolacce: Perché le diciamo, che cosa significano, quali effetti hanno. Milano: Bur, 2006.

ULLMANN, Stephen. Semântica: uma introdução à ciência do significado. Traduzido por J. A. Osório Mateus. Lisboa: Fundação Calouste Gulbenkian. 1967. Tradução de: Semantics Introduction to the Science of Meaning.

ZANNI, Marco. Ditelo com gli insulti: e non accontentatevi di un semplice vaffanculo. Milano: Baldini \& Castaldi, 2001.

ZINGARELLI, Nicola. Il Nuovo Zingarelli: Vocabolario della lingua italiana. Bologna: Zanichelli, 1983.

Artigo recebido em: 30.01 .2012

Artigo aprovado em: 15.06.2012 